Published on Reviews in History (https://reviews.history.ac.uk)

\title{
Rewriting Magic: An Exegesis of the Visionary Autobiography of a Fourteenth-Century French Monk
}

Review Number: 2064

Publish date: Thursday, 16 February, 2017

Author: Claire Fanger

ISBN: 9780271066509

Date of Publication: 2015

Price: $£ 54.61$

Pages: 232pp.

Publisher: Penn University Press

Publisher url: http://www.psupress.org/books/titles/978-0-271-06650-9.html

Place of Publication: Philadelphia, PA

Reviewer: Benedek Láng

Rewriting Magic is an unusual monograph both in its style and in its content. It is the latest publication in the Magic in History series by Penn State University Press. The Press started issuing this series more than two decades ago, and it has become by now a flourishing and exciting enterprise with nearly 20 titles including monographs, text editions and collections of essays. It is probably the most concentrated source of knowledge for any scholar of medieval magic. Most of the contemporary authors publishing on magic in English (including Frank Klaassen, Sophie Page, Michael Bailey, Jan Veenstra, Katelyn Mesler, Julien Veronese, Nicolas Weill-Parot, and many others) are represented in the series by a monograph or an article in a collection of essays.

Besides Richard Kieckhefer - author of the first book, Forbidden Rights, and originator of this and many other scholarly initiations on late medieval magic - it is probably Claire Fanger who contributed the most to the success of the Magic in History series. Reviewing, correcting and commenting on the monographs of her fellow scholars (certainly including the book of the author of this review), and editing two collections of essays, Conjuring Spirits: Texts and Traditions of Medieval Ritual Magic in 1998, and Invoking Angels: Theurgic Ideas and Practices, Thirteenth to Sixteenth Centuries in $2012 \underline{(1)}$, her impact on the accuracy, reliability, and richness of the series has been decisive.

Claire Fanger's present book on the early 14th-century monk, John of Morigny, and his magical-devotional enterprise, the Liber florum, has been long awaited - at least since the publication of Conjuring Spirits, from which the scholarly community on medieval magic first learned about her commitment to the topic.

However, the reader (at least this reader), expecting the book to conform to the normal objective tone of the series, and fit into the tradition founded by this very author, is in for a surprise. The style of Rewriting Magic is remarkably personal, and its nature is considerably more 'auto-biographical' than previous entries in the series. Claire Fanger, now having established how it is appropriate to write about magic, rewrites her rules. And this is what makes Rewriting Magic a really exciting read, the central theme being not only the medieval monk and his visionary book, but also a historical inquiry that lasted nearly two decades, involved a lot of colleagues, archives, and manuscripts. 
The result is in part a summary what is known today of John of Morigny's Liber florum - a Latin text that was published by the Pontifical Institute of Medieval Studies almost simultaneously with the story of its investigation.(2) However, Rewriting Magic is at least as much about the research methodology that proper scholars follow, about the machinery they have to invent for the investigation of something unknown, about the excitement and disappointment they face with in different phases of their investigations, about the discoveries they make, about the dead ends they enter in vain, about the initial wrong assumptions they have to leave behind eventually, and about the small signs they recognize as solutions for their enigmas, as it is about the medieval monk and his absolutely unique text.

But who was John of Morigny and what is the Liber florum? John was a French Benedictine monk who for a certain period practiced a magical ritual called Ars notoria in order to facilitate his ability to learn and read, but then - tortured by demons, and inspired by visions from Mary - he decided to give it up, and - following the Virgin's help - he prepared his own version in two phases. The first version of his book was probably well received in his closer, monastic circles, where John must have been seen with certain respect, but it was heavily criticized by the 'Barking Dogs', as he calls the hostile voices of authority that recognized illicit magic in his work. It was this - besides Mary's reservation towards certain parts of his work - that made him prepare his second, final version of the Liber florum, the so called New Compilation. The whole process took many years, from 1301 to 1315-16.

We are particularly well informed about the details of this rewriting, because John starts his book with an autobiographical prologue, in which he describes how he and his sister, Bridget had horrible visions on malign spirits because of their obsession of the Ars notoria..(3)

Virtually unknown previously, the Liber florum has grown in prominence the last 30 years. In 1987, J. Dupèbe mentioned it (4) and its condemnation in the context of other magical texts (particularly the Ars notoria).(5) This was followed by Sylvie Barnay's more detailed contextualization of the medieval history of Mary's apparitions, as Barnay had access to the whole text including its autobiographical prologue. $\underline{(6)}$

1998 saw the publication of Claire Fanger's edited book, Conjuring Spirits, in which articles by Nicholas Watson, Richard Kieckhefer and Fanger showed the role of John's text in the context of the genre of medieval ritual magic. Thanks to these and other essays from the same collection, ritual magic was thematized as a full-fledged research topic for historians and philologists.

After nearly two decades, Rewriting Magic now rewrites many of the facts we were supposed to know about John's text. First: its title. While medieval texts were rarely identified by stable titles in the Middle Ages, on textual evidence it seemed fairly reasonable to call John's text the Liber visionum, or 'Book of visions'. Fanger now points out that following John's explicit intentions, it should be rather called Liber florum celestis doctrine - The Flowers of Heavenly Teaching, only the first, autobiographical part of which is the Liber visionum. Other corrections concern the name of John's sister (Burgeta - Bridget instead of the earlier Gurgeta), the place of John's experiments with the Ars notoria (Orleans, instead of Chartres), and other details reconstructed on the basis of a growing body of manuscripts - around 23 of which have now been identified, all copied in the 14th and 15th (but surprisingly none in later) centuries.

As we learn directly from the text, John was an experienced practitioner of ritual magic, and knew and followed the Ars notoria - a method attributed to Salomon with the help of which knowledge of the liberal arts as well as memory and eloquence can be attained in an unrealistically short period through specific procedures involving prayers, rituals and suspicious figures. This was the reason why demons tortured him and his sister. But as Claire Fanger documents now, he was also familiar with many other magic works associated with Salomon, including the Four Rings of Salomon and the Book of the Semhemforas.

Traces of this background knowledge of John's were so obvious in the old Book of Figures (the third book of the Liber florum, which originally contained around 92 figures) that the 'Barking Dogs' felt obliged to 
condemn John's project heavily. As a consequence of this, and of Mary's ambivalence ('I'm telling you, I do not want prayers nor figures nor visualizations without your heart'), he decided to rewrite his book and got rid of most of the necromantic-looking figures.

However, it would be too easy and utterly misleading to position John as a lost monk who turned away from the Christian teachings and started following illicit magic. As a matter of fact, all medieval magic texts were written, translated and copied by monks, friars and university doctors - all of them being religious vocations to some extent (p. 45). Trying to understand medieval magic as opposed to Christianity is a misunderstanding. John can rather be situated as an actor in an ongoing debate (a 'conversation about orthodoxy and orthopraxis') starting with Augustine and lasting at least to the Renaissance, that tried to differentiate (or in the case of Augustine: refused to differentiate) between various types of magic. Most of the participants of this debate argued for the inclusion of some texts and rituals which seemed less illicit than the others. The Middle Ages produced many such classifications and differentiations - starting from Hugh of Saint Victor, through Thomas Aquinas and the famous anonym author of the Speculum astronomiae, up to Johannes Hartlieb and Johannes Trithemius - testifying to a living interest in what can be called 'weakly sinful kinds of necromancy' (as opposed to strongly sinful kinds of necromancy - p. 113). 'It is against this background of conceptual gradations of illicit magic that John of Morigny's ongoing engagement with necromancy must be seen' (p. 116). Medieval magic texts varied in the extent to which they could be identified as Christian. John's purpose was clearly at the most Christian extreme, as he tried to 'adapt and develop the visual lexicon of image magic' (p. 128) and integrate 'magical and other forms of knowledge with theology, prayer, and devotion to the Virgin' (p. 132.).

The novelty of Rewriting Magic is that it contextualizes the Liber florum not only in the framework of medieval magic (where it had already been sited, not least by the very author of the book), but also in the framework of medieval practices of devotion, confession, and penance. 'For a monk like John of Morigny, the attractive feature of the ars notoria was surely not so much that it appeared to be magic, but that it appeared to be a specifically targeted form of devotion that would enable the necessary reform of self that allowed knowledge to be accessed and retained' (p. 56). John's history is about turning away from the magical arts, about the renunciation of necromancy, and about a deeply Christian reinterpretation of ars notoria rituals, the tetragrammaton, and necromantic figures in a beautiful autobiographical prologue, and in a long set of prayers and figures - with the constant and explicit help of the Virgin Mary who seems to have 'particular responsibility for the restoration of knowledge' (p. 77).

This book is the chronicle of an intellectual trip, the diary of a process that has lasted more than 20 years. It has not yet finished, as the critical edition of the Latin text has just been published, and the English translation is in progress. Still, as the author emphasizes, in spite of enormous research and the great number of identified and analyzed manuscripts, one cannot claim that 'the real' John of Morigny has been grasped. What can be claimed with certainty is that the John of Morigny Claire Fanger portrays is real. John was a 'visionary, exegete, storyteller, sinner, and penitent, friend of the Virgin Mary, a man who had faith that God wanted his book to be written so that it could be read' (p. 168). Thanks to this book, this person can now be understood and empathized with by any reader.

\section{Notes}

1. Claire Fanger, Conjuring Spirits: Texts and Traditions of Medieval Ritual Magic (University Park, PA, 1998); Invoking Angels: Theurgic Ideas and Practices, Thirteenth to Sixteenth Centuries (University Park, PA, 2012). Back to (1)

2. John of Morigny. Liber florum celestis doctrine / The Flowers of Heavenly Teaching, ed. Claire Fanger and Nicholas Watson (Toronto, 2015).Back to (2)

3. This prologue has been available since 2001 thanks to the same editors, Claire Fanger and her collegaue, Nicholas Watson, whose text edition was based on Graz, University Library MS 680: 'The Prologue to John of Morigny's Liber Visionum: Text and Translation', Esoterica: The Journal of Western Esoteric Studies 
, 3 (2001) <http://www.esoteric.msu.edu [2]> [accessed 27 January 2017].Back to (3)

4. MS Munich, Bayerische Staatsbibliothek CLM 276.Back to (4)

5. J. Dupèbe, 'L'Ars Notoria et la polémique sur la divination et la magie', in Divination et Contreverse Religieuse en France au XVIe siècle (Paris, 1987), pp. 123-34.Back to (5)

6. Sylvie Barnay, 'La mariophanie au regard de Jean de Morigny: magie au miracle de la vision mariale', in Miracles, Prodiges et Merveilles au Moyen Age (Paris, 1995), 173-190; 'Désir de voir et interdits visionnaires ou la "mariophanie" selon Jean de Morigny (XIVe siècle)', in Homo Religiosus (Paris, 1997), pp. 519-26. Back to (6)

The author is happy to see the aims of her book so well received and understood; she does not wish to comment further.

Source URL:https://reviews.history.ac.uk/review/2064

\section{Links}

[1] https://reviews.history.ac.uk/item/161328 [2] http://www.esoteric.msu.edu/ 